Supporting information for

\title{
A Water-soluble, Small Molecular Fluorescent Sensor with Femtomolar Sensitivity for Zinc Ions
}

\author{
Huan-Huan Wang, Quan Gan, Xiao-Jun Wang, Lin Xue, Sheng-Hua Liu and Hua Jiang* \\ Beijing National Laboratory for Molecular Sciences, CAS Key Laboratory of Photochemistry, \\ Institute of Chemistry, Chinese Academy of Sciences, Beijing, 100080, P. R. China, College of \\ Chemistry, Central China Normal University, Wuhan, Hubei, 430079 China, Graduate School of \\ Chinese Academy of Sciences, Beijing, China, Department of Chemistry, Capital Normal \\ University, Beijing, China \\ hjiang@iccas.ac.cn
}

Contents

1 Synthetic Procedures

2 Experimental Section

3 Determination of Quantum Yields 


\section{Synthetic procedures for 1}<smiles>Cc1ccc2cccc(O)c2n1</smiles>

$$
\begin{aligned}
& \stackrel{\mathrm{BrCH}_{2} \mathrm{CO}_{2} \mathrm{Et}}{\longrightarrow} \\
& \text { Acetone } / \mathrm{K}_{2} \mathrm{CO}_{3} \\
& \text { Reflux, 24h, 81\% }
\end{aligned}
$$

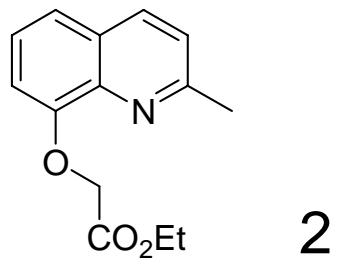

A mixture of 8-hydroxy-2-methylquinoline (3.2 g), ethyl bromoacetate (3.2 g) and $\mathrm{K}_{2} \mathrm{CO}_{3}(10 \mathrm{~g})$ in acetone $(30 \mathrm{~mL})$ was refluxed for $24 \mathrm{~h}$. After cooling, the mixture was filtered and evaporated to generate crude residue, which was purified by chromatography (silica gel, DCM/0-1\% methanol) to give $4.0 \mathrm{~g}$ oil. Yield: $81 \%$. ${ }^{1} \mathrm{H}$ NMR (300 MHz, $\left.\mathrm{CDCl}_{3}, \mathrm{ppm}\right): \delta 8.00(1 \mathrm{H}, \mathrm{d}, J=8.4 \mathrm{~Hz}), 7.42 \sim 7.30(3 \mathrm{H}, \mathrm{m}), 6.96(1 \mathrm{H}$, q, $J=1.4 \mathrm{~Hz}, J=6.0 \mathrm{~Hz}), 4.96(2 \mathrm{H}, \mathrm{s}), 4.26(2 \mathrm{H}, \mathrm{q}, J=7.1 \mathrm{~Hz}), 2.79(3 \mathrm{H}, \mathrm{s}), 1.28(3 \mathrm{H}, \mathrm{t}$, $J=7.1 \mathrm{~Hz}) .{ }^{13} \mathrm{C} \mathrm{NMR}\left(100 \mathrm{MHz}, \mathrm{CDCl}_{3}, \mathrm{ppm}\right): \delta 169.3,158.44,153.10,139.61,136.18$, $127.86,125.37,122.77,120.87,110.00,66.40,61.41,25.50,14.19$.
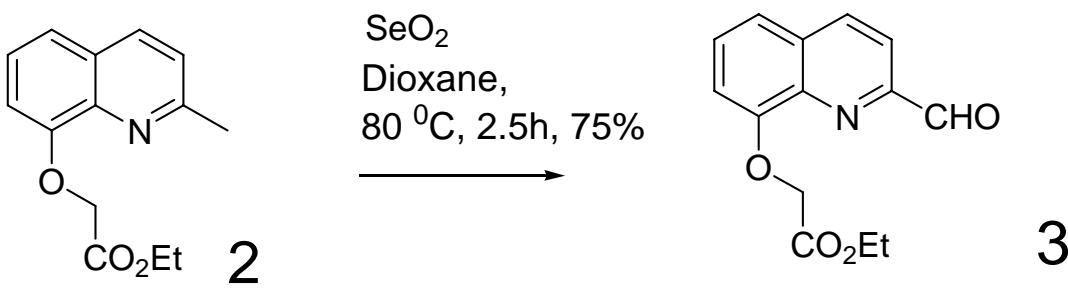

A solution of $2(1.5 \mathrm{~g})$ in dioxane $(20 \mathrm{~mL})$ was heated to $65^{\circ} \mathrm{C}$. To this solution was added $\mathrm{SeO}_{2}(0.75 \mathrm{~g})$. Then the temperature was increased to $80^{\circ} \mathrm{C}$. After $2 \mathrm{~h}$, the mixture was cooled to ambient temperature. The precipitate was filtered off. Organic phase was concentrated. The pure product was obtained by recrystallization from ethyl acetate/hexane. ${ }^{1} \mathrm{H}$ NMR $\left(400 \mathrm{MHz}, \mathrm{CDCl}_{3}, \mathrm{ppm}\right) \delta 10.31(1 \mathrm{H}, \mathrm{s}), 8.30(1 \mathrm{H}, \mathrm{d}$, $J=8.5 \mathrm{~Hz}), 8.42(1 \mathrm{H}, \mathrm{d}, J=8.2 \mathrm{~Hz}), 7.57(2 \mathrm{H}, \mathrm{m}), 7.08(1 \mathrm{H}, \mathrm{d}, J=7.6 \mathrm{~Hz}), 5.03(2 \mathrm{H}, \mathrm{s})$, $4.47(2 \mathrm{H}, \mathrm{q}, J=7.0 \mathrm{~Hz}), 1.30(3 \mathrm{H}, \mathrm{t}, J=7.1 \mathrm{~Hz}) \cdot{ }^{13} \mathrm{C} \mathrm{NMR}\left(100 \mathrm{MHz}, \mathrm{CDCl}_{3}, \mathrm{ppm}\right): \delta$ $193.76,168.54,164.44,154.50,151.76,145.09,140.06,138.75,37.47,131.57$, 129.47, 121.06, 120.97, 119.96, 118.07, 111.44, 110.95, 66.62, 61.80, 61.65, 14.282. 
<smiles>CCOC(=O)COc1cccc2ccc(C=O)nc12</smiles>

2, 2 -Dipicolylamine, $\mathrm{NaB}(\mathrm{OAc})_{3} \mathrm{H}, \mathrm{rt}, 72 \%$

3

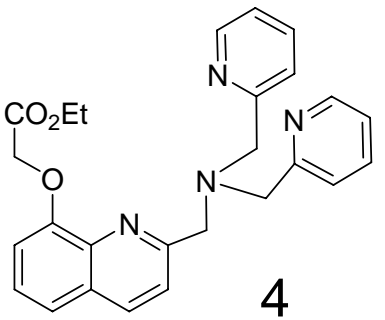

To a mixture of $3(0.4 \mathrm{~g})$ and 2, 2-dipicolylamine $(0.3 \mathrm{~g})$ in 1, 2-dichloroethane $(20 \mathrm{~mL})$ was added $\mathrm{NaBH}(\mathrm{OAc})_{3}(0.41 \mathrm{~g})$. The resulting solution was stirred at room temperature overnight. The solution was acidified with $1 \mathrm{~N} \mathrm{HCl}$ to $\mathrm{pH} 4-5$, then neutralized with $1 \mathrm{~N} \mathrm{NaOH}$ to $\mathrm{pH}$ 7-8. Organic phase was separated. Aqueous phase was extracted with DCM $(2 \times 20 \mathrm{~mL})$. Organic phases were combined and dried over $\mathrm{Na}_{2} \mathrm{SO}_{4}$. The solvents were evaporated to give crude solid, which was purified by recrystallization from ethyl acetate/hexane to generate pale yellow or colorless solid (72\%). The crystals are good enough for X-ray diffraction. Mp: $125-127^{\circ} \mathrm{C} .{ }^{1} \mathrm{H}$ NMR $\left(400 \mathrm{MHz}, \mathrm{CDCl}_{3}, \mathrm{ppm}\right) \delta 8.53(2 \mathrm{H}, \mathrm{d}, J=4.7 \mathrm{~Hz}), 8.09(1 \mathrm{H}, \mathrm{d}, J=8.5 \mathrm{~Hz}), 7.86(1 \mathrm{H}, \mathrm{d}$, $J=8.5 \mathrm{~Hz}), 7.68 \sim 7.60(4 \mathrm{H}, \mathrm{m}), 7.43 \sim 7.35(2 \mathrm{H}, \mathrm{m}), 7.15 \sim 7.12(2 \mathrm{H}, \mathrm{m}), 4.97(2 \mathrm{H}, \mathrm{d}$, $J=7.8 \mathrm{~Hz}), 4.27(1.5 \mathrm{H}, \mathrm{q}, J=7.1 \mathrm{~Hz}), 4.10(2 \mathrm{H}, \mathrm{s}), 3.92(4 \mathrm{H}, \mathrm{s}), 3.79(0.5 \mathrm{H}, \mathrm{s}), 1.27(2 \mathrm{H}, \mathrm{t}$, $J=7.1 \mathrm{~Hz}) .{ }^{13} \mathrm{C} \mathrm{NMR}\left(100 \mathrm{MHz}, \mathrm{CDCl}_{3}, \mathrm{ppm}\right): \delta 169.04,159.57,159.38,153.59$, $149.14,139.67,136.41,128.76,125.88,123.12$, 122.00, 121.33, 121.01, 111.07, 66.92, 61.23, 60.91, 60.62, 60.32, 14.18. Mass (ESI-MS): m/z 465.4 (M+Na $\left.{ }^{+}\right), 443.4$ $\left(\mathrm{M}+\mathrm{H}^{+}\right)$<smiles>CCOc1cccc2ccc(CN(Cc3ccccn3)Cc3ccccn3)nc12</smiles>
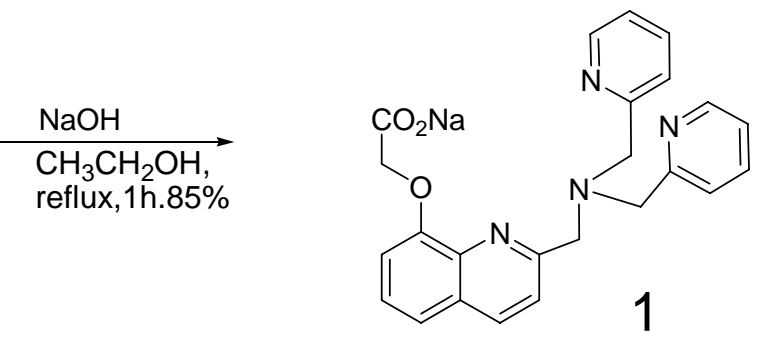

To a solution of $4(0.21 \mathrm{~g})$ in $95 \%$ ethanol $(5 \mathrm{~mL})$ was added sodium hydroxide (2.5 eq.). The solution was refluxed for $1 \mathrm{~h}$. After cooling, most solvent was removed. The rest solution was cooled at $4{ }^{\circ} \mathrm{C}$ overnight. The crystals were filtered off and dried over vacuum. ${ }^{1} \mathrm{H}$ NMR(400MHz, DMSO-d6, ppm): $\delta 8.57(2 \mathrm{H}, \mathrm{d}, J=4.1 \mathrm{~Hz})$, $8.30(1 \mathrm{H}, \mathrm{d}, J=8.4 \mathrm{~Hz}), 7.70(2 \mathrm{H}, \mathrm{m}), 7.55(1 \mathrm{H}, \mathrm{d}, J=8.5 \mathrm{~Hz}), 7.47(2 \mathrm{H}, \mathrm{d}, J=4.4 \mathrm{~Hz})$, 
7.33(2H, d, $J=7.6 \mathrm{~Hz}), 7.23(2 \mathrm{H}, \mathrm{m}), 7.17(1 \mathrm{H}, \mathrm{t}, J=2.2 \mathrm{~Hz}), 4.35(2 \mathrm{H}, \mathrm{s}), 4.03(2 \mathrm{H}, \mathrm{s})$, 3.78(2H, s). $\left.{ }^{13} \mathrm{C} \mathrm{NMR} \mathrm{(100MHz,} \mathrm{CDCl}_{3}, \mathrm{ppm}\right): \delta 172.33,157.41,157.06,152.94$, $151.24,139.60,137.12,137.04,128.30,127.08,123.26,122.91,121.39,119.20$, 109.12, 67.91, 60.12, 59.84. Anal. Calcd for $\mathrm{C}_{24} \mathrm{H}_{21} \mathrm{~N}_{4} \mathrm{NaO}_{3} \cdot 1.5 \mathrm{H}_{2} \mathrm{O}: \mathrm{C}: 62.20 ; \mathrm{H}$ : 5.22; N: 12.09; Found: C: 62.03; H: 5.05; N: 12.01.
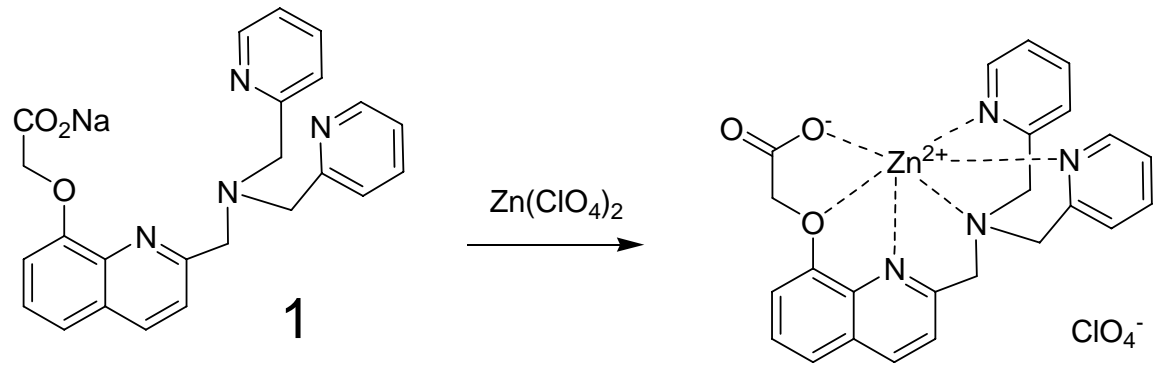

$1(21 \mathrm{mg})$ was dissolved in $6 \mathrm{~mL}$ methanol containing $10 \%$ water. To the solution was added $\mathrm{Zn}\left(\mathrm{ClO}_{4}\right)_{2}(18 \mathrm{mg}$, 1eq. $)$ at room temperature. The mixture was shaken for $10 \mathrm{~min}$. An aliquot of complex solution $(1.5 \mathrm{~mL})$ was placed into a glass tube. Then ethyl ether was added carefully into the tube to precipitate the zinc complex of $\mathbf{1}$. After 5 days, the crystals appeared in the tube and were ready for X-ray diffraction. ${ }^{1} \mathrm{H}$ NMR $\left(300 \mathrm{MHz}, \mathrm{D}_{2} \mathrm{O}, \mathrm{ppm}\right) \delta 8.60(2 \mathrm{H}, \mathrm{d}, J=5.1 \mathrm{~Hz}), 8.54(1 \mathrm{H}, \mathrm{d}, J=8.5 \mathrm{~Hz})$, 8.05 8.10(2H, m), 7.48 7.71(7H, m), 7.46(1H, d, $J=6.6 \mathrm{~Hz}), 5.09(2 \mathrm{H}, \mathrm{s}), 4.28 \sim 4.43$ $(6 \mathrm{H}, \mathrm{m})$.

\section{Experimental Sections}

All titrations experiments were carried out in aqueous buffer $(25 \mathrm{mM}$ HEPES, $0.1 \mathrm{M} \mathrm{NaClO}_{4}, \mathrm{pH}=7.4,25^{\circ} \mathrm{C}$ ). $\mathrm{UV}$-vis and fluorescence spectra were recorded on HITACHI 3010 UV-vis spectrometer and HITACHI F-4500 spectrometer, respectively. Both excitation and emission slits are $5 \mathrm{~mm}$. All titrations experiments were run twice for reliable data. All proton and ${ }^{13} \mathrm{C}$ NMR were measured on Bruker NMR spectrometer. Elemental analysis was measured on FLASH EA1112. 


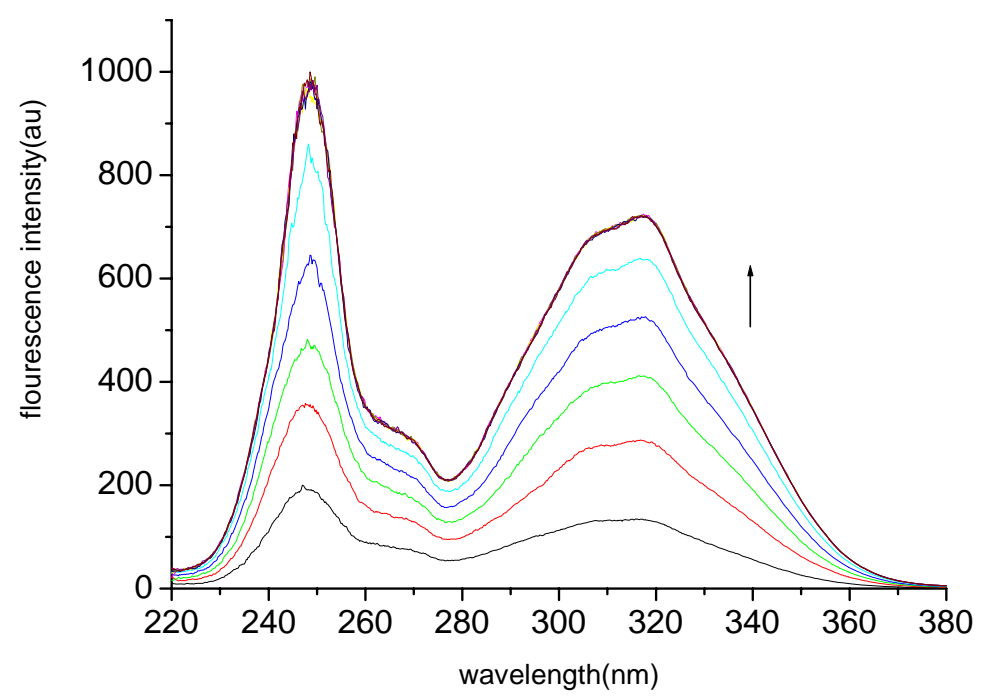

Figure S1 Excitation fluorescence spectra $\left(\lambda_{\mathrm{em}}=440 \mathrm{~nm}\right)$ of 1 upon titration of zinc (0-1 equiv). The spectra were measured at $25^{\circ} \mathrm{C}$ and $25 \mathrm{mM}$ HEPES, $100 \mathrm{mM} \mathrm{NaClO}_{4}, \mathrm{pH} 7.4$ buffer solution.

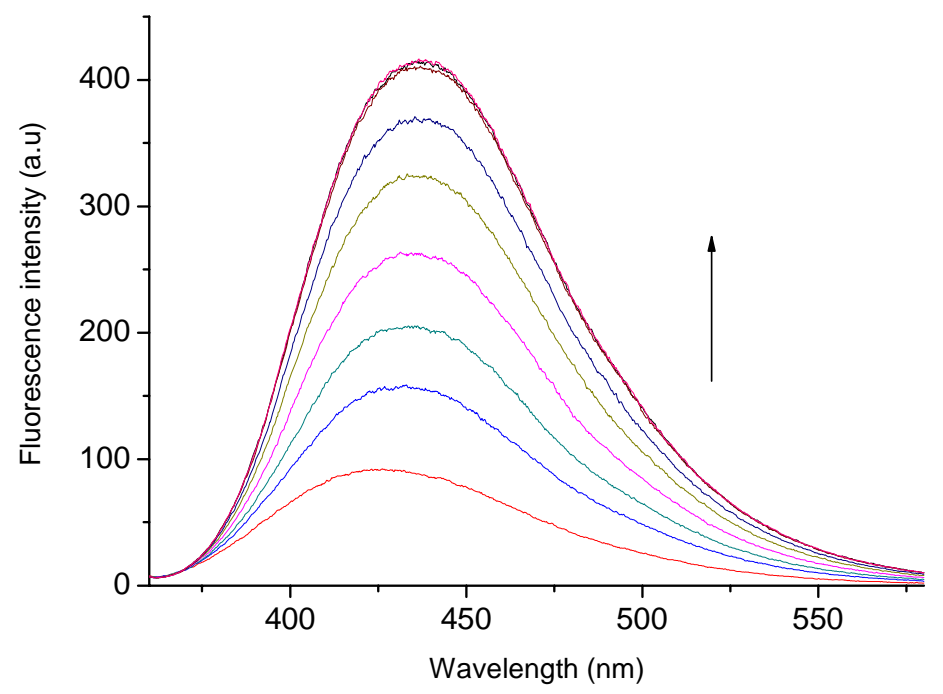

Figure S2 Fluorescence emission spectra of $1(5 \mu \mathrm{M})$. The spectra were measured at $25^{\circ} \mathrm{C}$ and 25mM HEPES, $100 \mathrm{mM} \mathrm{NaClO}_{4}$, $\mathrm{pH} 7.4$ buffer solution. The zinc(II) concentrations varied from 0 to $5 \mu \mathrm{M}$. 


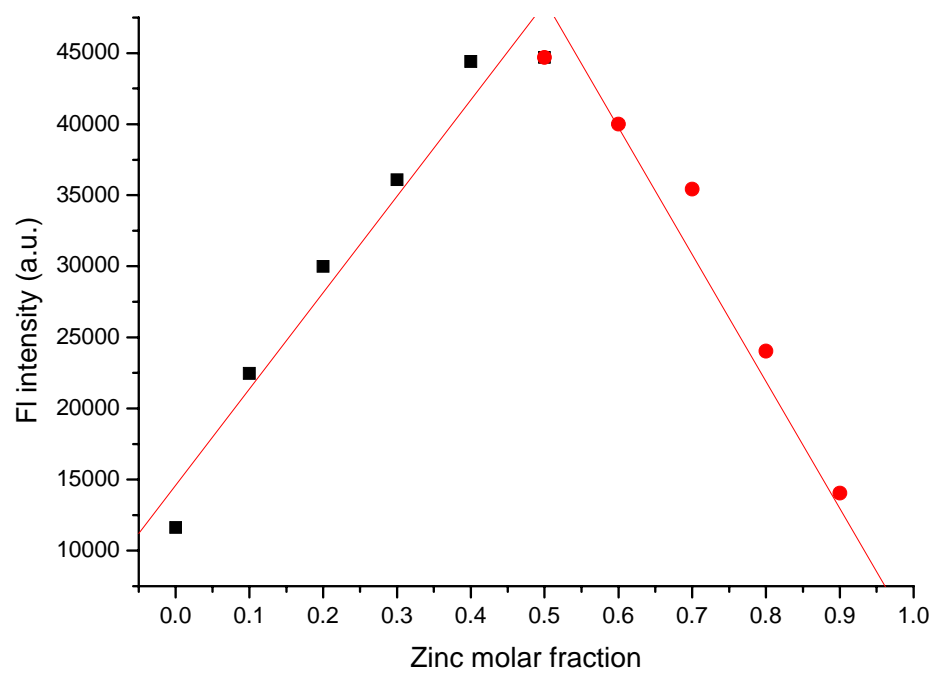

Figure S3 Job's plot of 1 and Zinc (II). The total concentrations of $\mathbf{1}$ and Zinc(II) are $12.5 \mu \mathrm{M}$. The fluorescence emission spectra were measured at $25^{\circ} \mathrm{C}$ and $25 \mathrm{mM}$ HEPES, $100 \mathrm{mM} \mathrm{NaClO}_{4}, \mathrm{pH}$ 7.4 buffer solution. Job's plot indicates a 1:1 binding model.
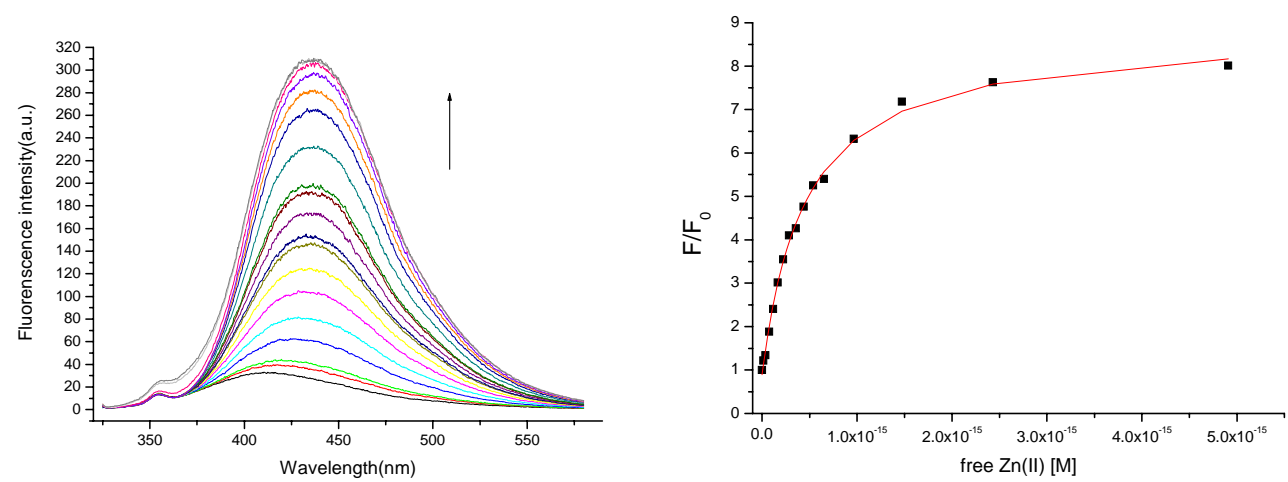

Figure S4. Fluorescence emission spectra of $\mathbf{1}(2.5 \mu \mathrm{M})$ in Zinc(II) - TPEN buffer solutions in the presence of 1 eq. $\mathrm{Ca}^{2+}$. Left:The spectra were measured at $25^{\circ} \mathrm{C}, \mathrm{pH} 7.4$ in buffered zinc(II) solution comprising $25 \mathrm{mM}$ HEPES, $0.1 \mathrm{M} \mathrm{NaClO}$, $0.25 \mathrm{mM}$ total TPEN, and 0-0.24 mM $\mathrm{Zn}\left(\mathrm{ClO}_{4}\right)_{2}$. Right: Ratio of intergrated fluorescence intensity to apoligand as function of the concentration of free zinc (II). The data were fitted to be a 1:1 binding model according to following equation to generate $\log \mathrm{K}_{\mathrm{d}}=-15.34 \pm 0.03\left(\mathrm{R}^{\wedge} 2=0.997\right)$.

$$
F=F_{0}+\left(F_{\max }-F_{0}\right) \frac{[Z n(I I)]_{\text {free }}}{K_{d}+[Z n(I I)]_{\text {free }}}
$$




\section{Determination of quantum yields}

Fluorescence quantum yields were determined in the reference of quinine sulfate $(\Phi=0.54)$ in $0.1 \mathrm{~N} \mathrm{H}_{2} \mathrm{SO}_{4}$ at $348 \mathrm{~nm}$ excitation.

The quantum yields of $\mathbf{1}$ and its zinc complex are calculated according to following equation.

$$
\Phi_{\mathrm{x}}=\Phi_{\mathrm{s}}\left(\mathrm{A}_{\mathrm{s}} \mathrm{S}_{\mathrm{x}}\right) /\left(\mathrm{A}_{\mathrm{x}} \mathrm{S}_{\mathrm{s}}\right)\left(\mathrm{n}_{\mathrm{x}} / \mathrm{n}_{\mathrm{s}}\right)
$$

$\mathrm{A}_{\mathrm{x}}$ and $\mathrm{A}_{\mathrm{s}}$ are the absorbance of $\mathbf{1}$, its zinc complex and the standard. $\mathrm{S}_{\mathrm{x}}$ and $\mathrm{S}_{\mathrm{s}}$ are integrated fluorescence emission corresponding to 1, its zinc complex and the standard. $\mathrm{n}$ is the refractive index of the solvent.

\section{X-ray crystallography}

Intensity data collection was carried out with a Bruker APEXII diffractometer equipped with a CCD detector using $\mathrm{Mo} \mathrm{K}_{\alpha}$ monochromatized radiation $(\lambda=0.71073$ $\AA$ ) at room temperature. The raw frame data were integrated into SHELX-format reflection files and corrected for Lorentz and polarization effects using SAINT[1]. Corrections for incident and diffracted beam absorption effects were applied using SADABS[1]. The structure was solved by direct method and refined by full-matrix least-squares method on $F^{2}$ using the SHELXTL 97 software package [2]. All non-hydrogen atoms were refined anisotropically. Positions of hydrogen atoms attached to carbon atoms were fixed at their ideal positions, and those attached to oxygen atoms could not be located. 
Table S1 Crystal data and structure refinement of $\mathbf{4}$ and zinc complex of $\mathbf{1}$

\begin{tabular}{lll}
\hline & \multicolumn{1}{c}{4} & \multicolumn{1}{c}{ Zinc complex of 1} \\
\hline Empirical formula & $\mathrm{C}_{26} \mathrm{H}_{26} \mathrm{~N}_{4} \mathrm{O}_{3}$ & $\mathrm{C}_{51} \mathrm{H}_{54} \mathrm{Cl}_{2} \mathrm{~N}_{8} \mathrm{O}_{17} \mathrm{Zn}_{2}$ \\
Formula weight & 442.51 & 1252.66 \\
Crystal size [mm] & $0.26 \times 0.24 \times 0.22$ & $0.32 \times 0.28 \times 0.24$ \\
Crystal system & Triclinic & Triclinic \\
Space group & $\mathrm{P}-1$ & $\mathrm{P}-1$ \\
$a[\AA]$ & $8.7696(5)$ & $10.4480(2)$ \\
$b[\AA]$ & $11.2545(6)$ & $12.9271(3)$ \\
$c[\AA]$ & $12.6605(7)$ & $22.4611(5)$ \\
$\alpha[$ deg] & $111.203(4)$ & $97.7400(10)$ \\
$\beta[$ deg] & $93.678(4)$ & $90.6290(10)$ \\
$\gamma$ [deg] & $93.657(4)$ & $109.3540(10)$ \\
Volume $\left[\AA^{3}\right], Z$ & $1157.48(11), 2$ & $2831.11(11), 2$ \\
$D_{\text {calcd. }}\left[\mathrm{g} / \mathrm{cm}{ }^{3}\right]$ & 1.270 & 1.469 \\
$\mu$ [mm $\left.{ }^{-1}\right], F(000)$ & $0.085,468.0$ & $1.018,1292.0$ \\
Reflections collected & 16755 & 44327 \\
Unique reflections & 5635 & 13954 \\
$R_{\text {int }}$ & 0.0348 & 0.0464 \\
Final $R$ indices & $R_{1}=0.0559$, & $R_{1}=0.0615$, \\
{$[\mathrm{I}>2 \sigma(\mathrm{I})]^{\mathrm{a}}$} & $w R_{2}=0.1022$ & $w R_{2}=0.1696$ \\
$R$ indices & $R_{1}=0.1119$, & $R_{1}=0.1051$, \\
Goodl data] & 1.042 & $w R_{2}=0.1964$ \\
\hline & & 1.033 \\
\hline
\end{tabular}

$$
{ }^{a} R_{1}=\sum|| F_{o}|-| F_{c}|| / \sum\left|F_{o}\right| ; \quad w R_{2}=\left\{\sum\left[w\left(F_{o}^{2}-F_{c}^{2}\right)^{2}\right] / \sum\left[w\left(F_{o}^{2}\right)^{2}\right]\right\}^{1 / 2}
$$

[1] Bruker Analytical X-ray Systems, Inc.: Madison, WI, 1998.

[2] G. M. Sheldrick, SHLEXL97, Program for Crystal Structure Refinement, University of Göttingen, Germany, 1997. 


\section{NMR spectra}

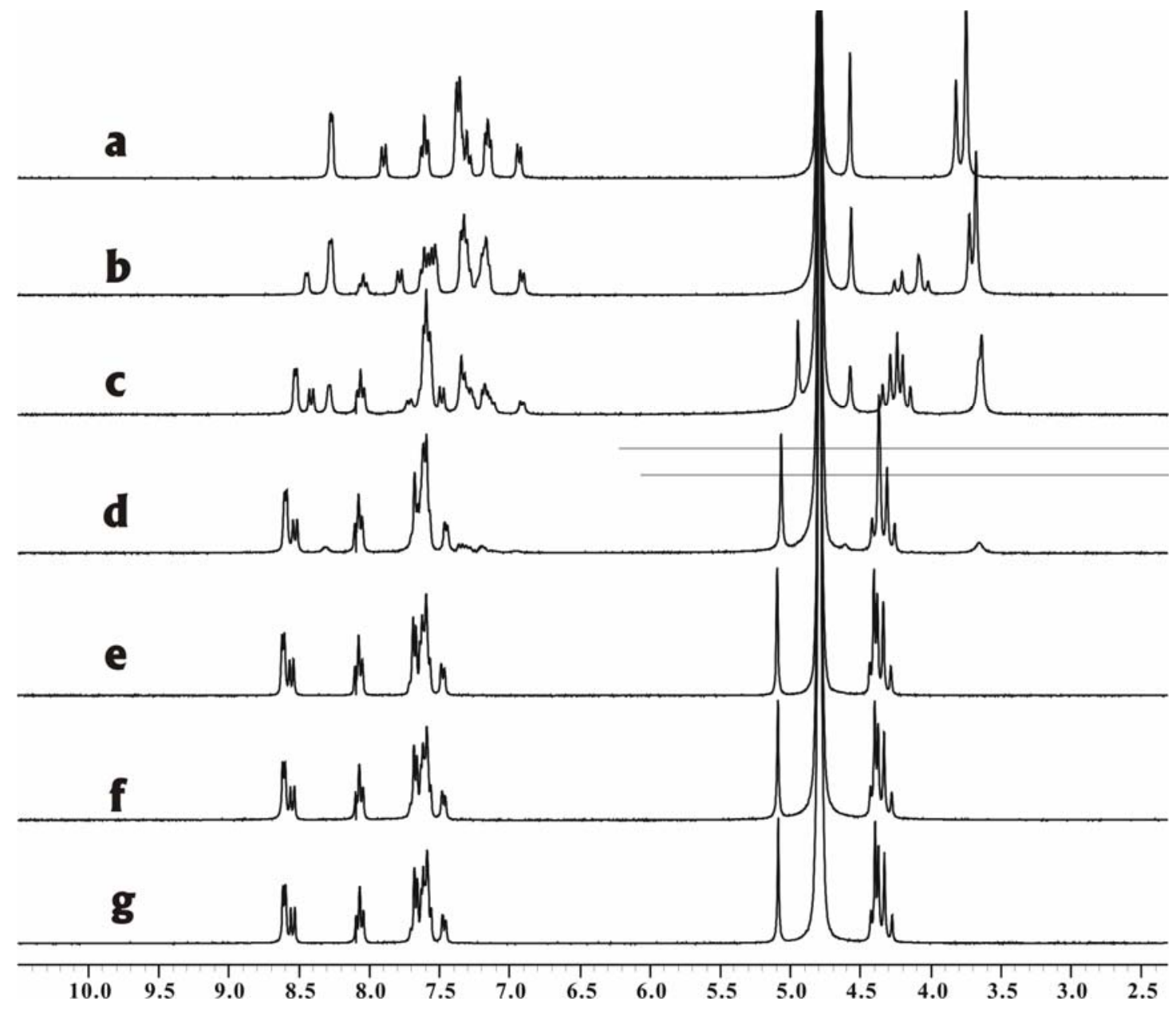

Figure S5. ${ }^{1} \mathrm{H}$ NMR (300 MHz) spectral changes of $1(10 \mathrm{mM})$ in $\mathrm{D}_{2} \mathrm{O}$ upon addition of $\mathrm{Zn}\left(\mathrm{NO}_{3}\right)_{2}$ in $\mathrm{D}_{2} \mathrm{O}$ at $298 \mathrm{~K}$. (a) $\mathbf{1}$, (b) $\mathbf{1}+\mathrm{Zn}^{2+}$ (4:1), (c) $\mathbf{1}+\mathrm{Zn}^{2+}(2: 1)$, (d) $\mathbf{1}+\mathrm{Zn}^{2+}$ (4:3), (e) $\mathbf{1}+\mathrm{Zn}^{2+}$ (1:1), (f) $\mathbf{1}+\mathrm{Zn}^{2+}(1: 1.5),(\mathrm{g}) \mathbf{1}+\mathrm{Zn}^{2+}(1: 2)$. 


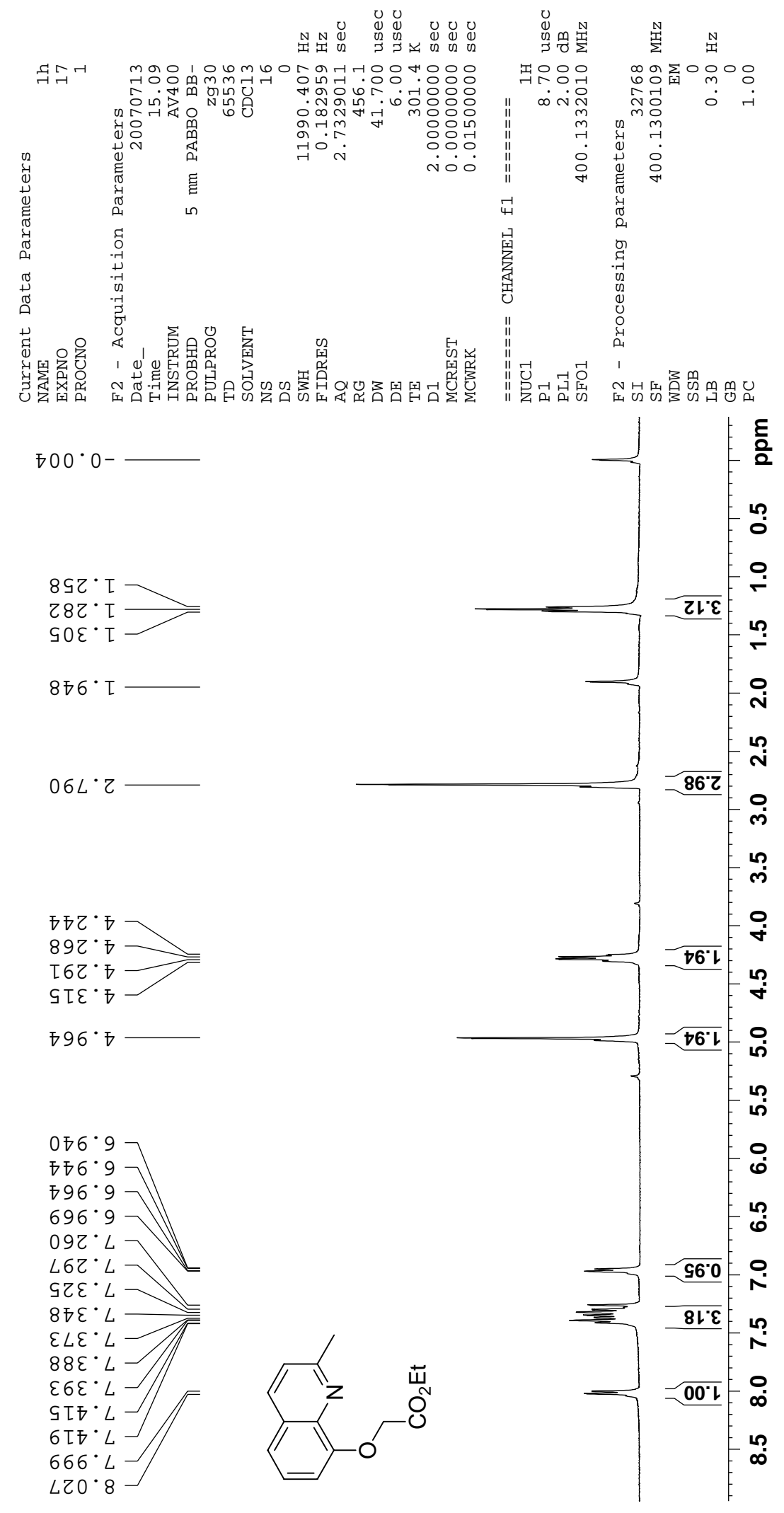




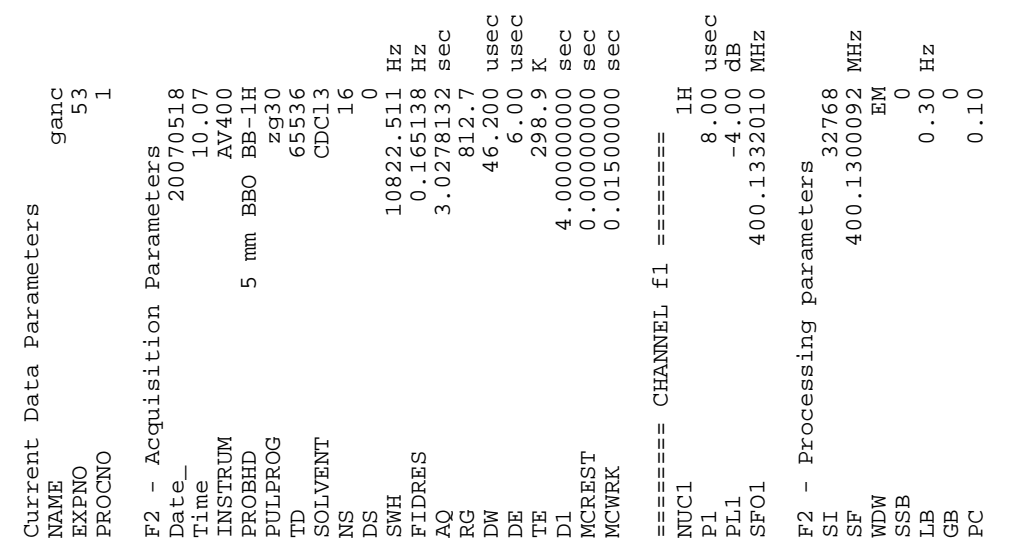

乙०० ० -
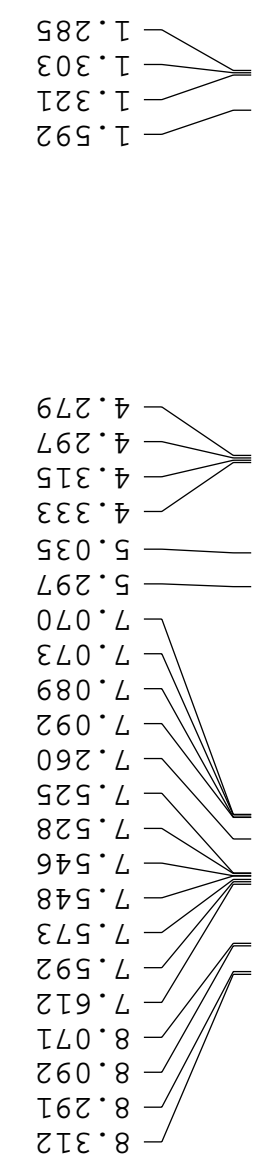

乙IE' ०I $\varepsilon \tau \varepsilon \cdot O \tau \longrightarrow$

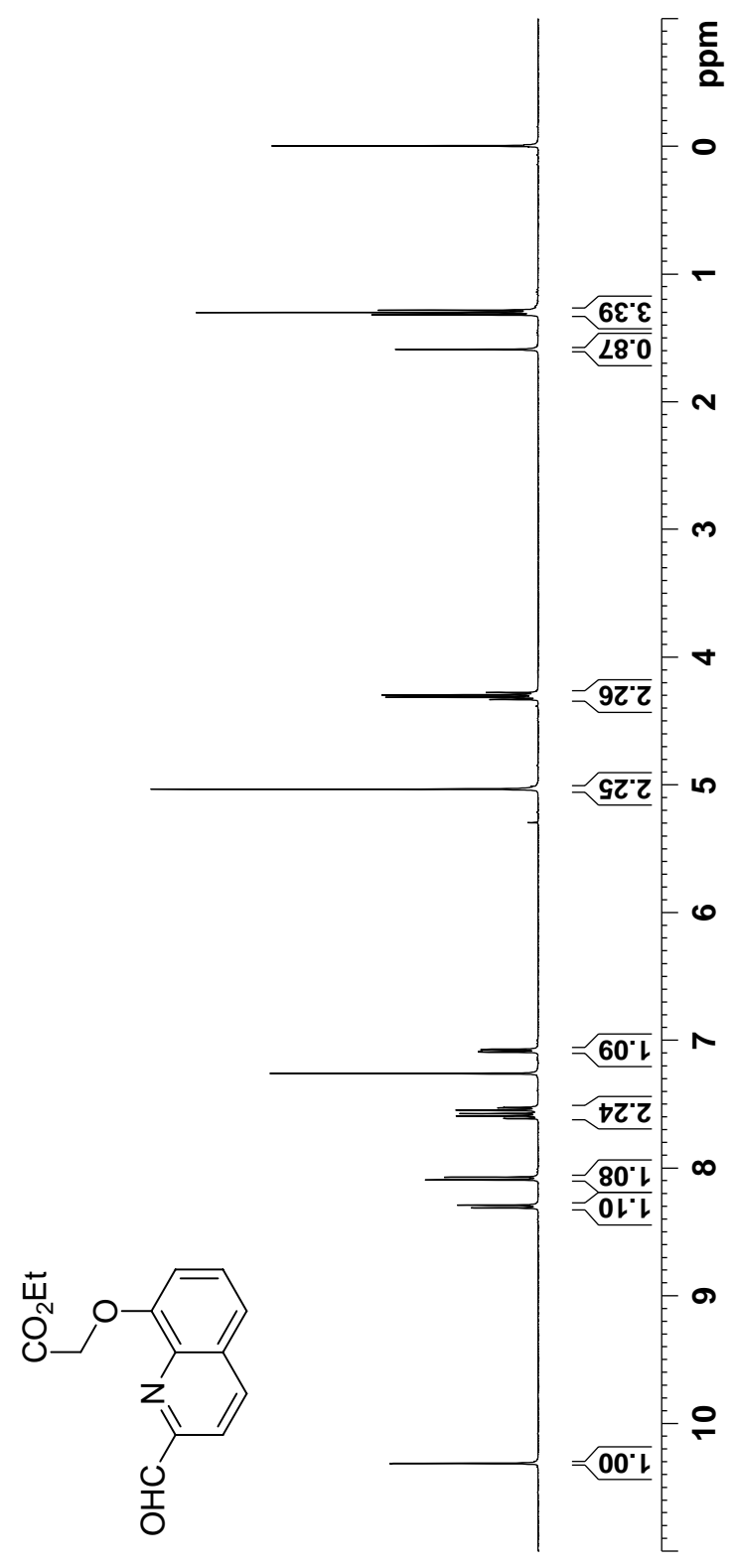




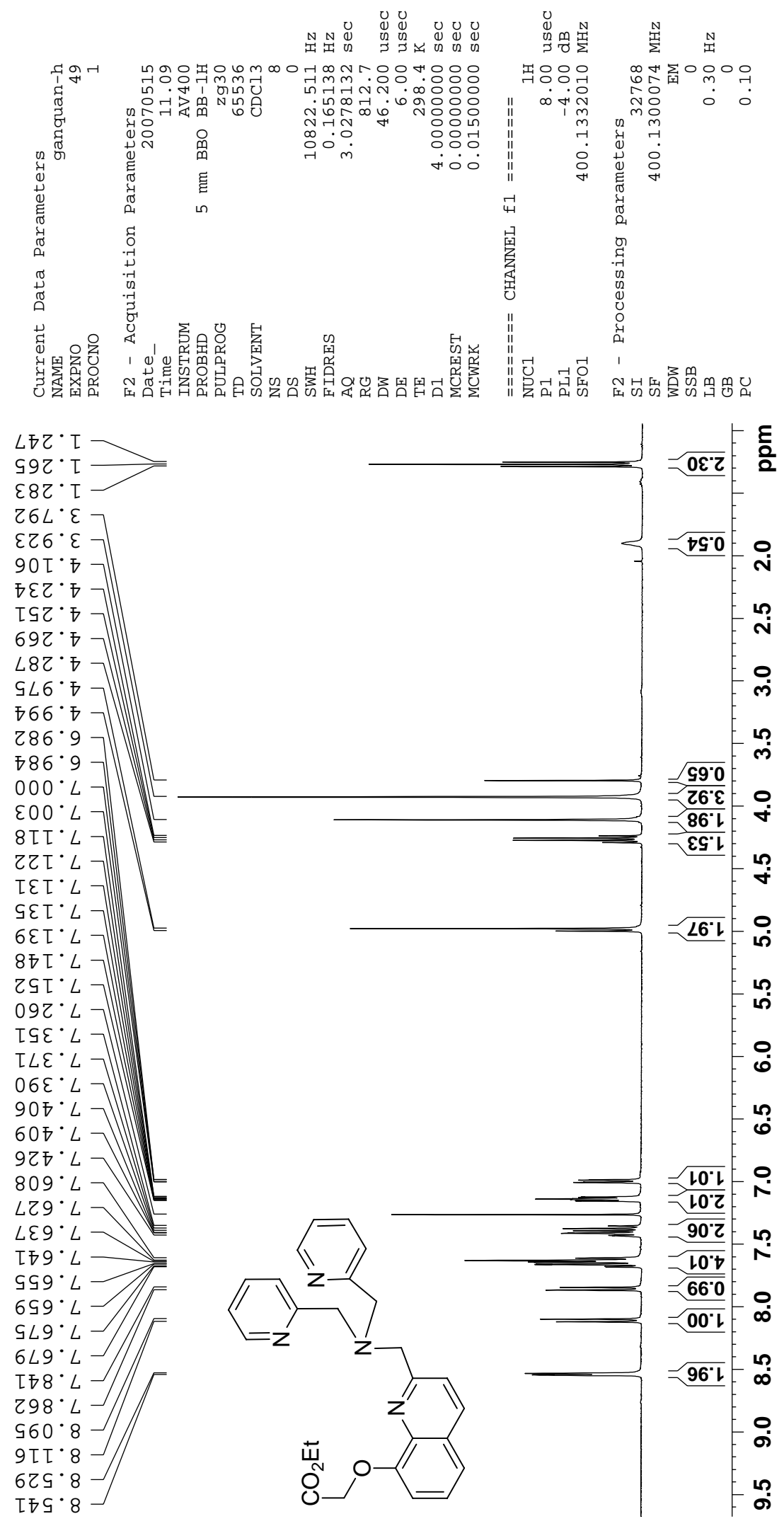




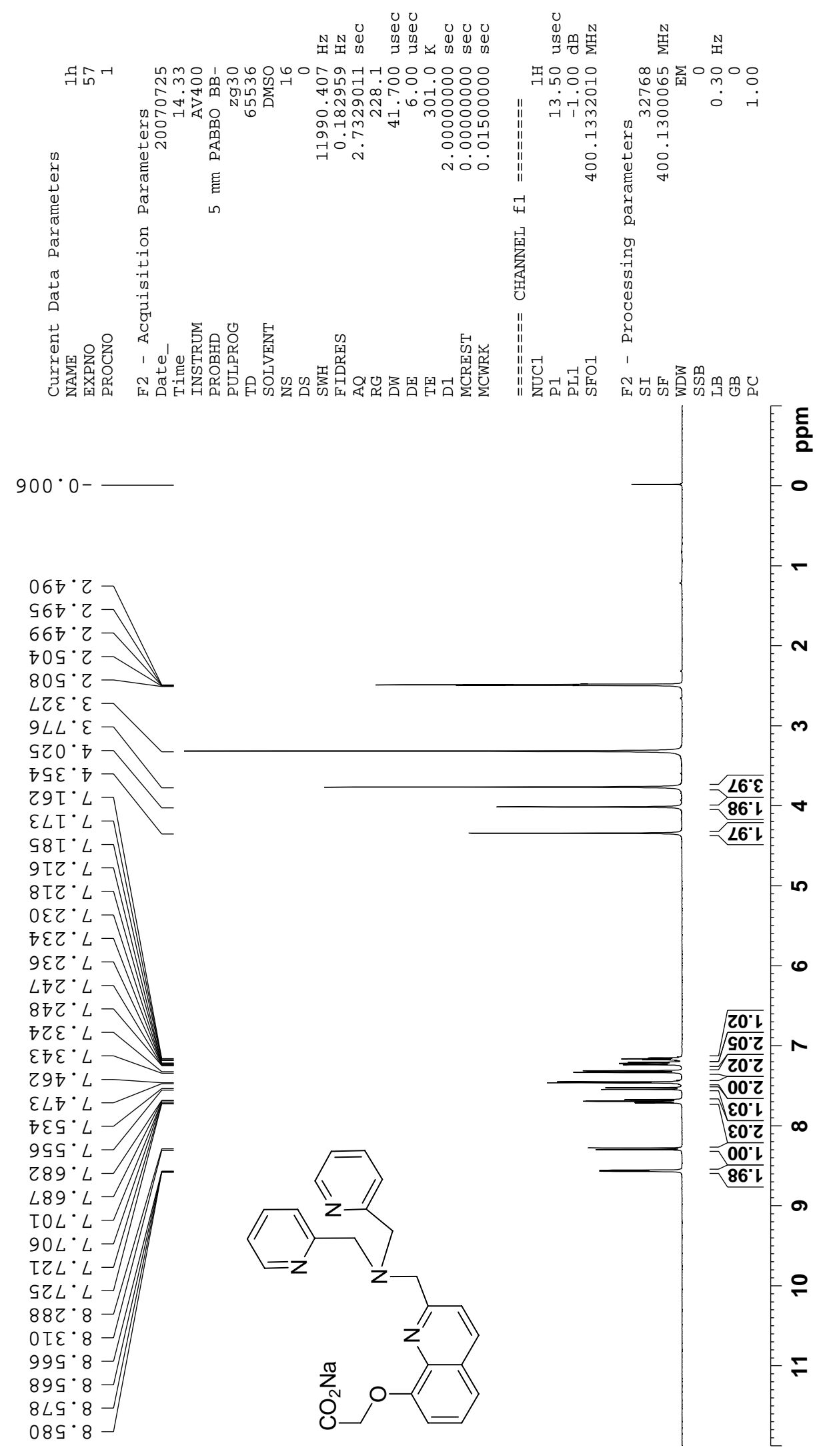




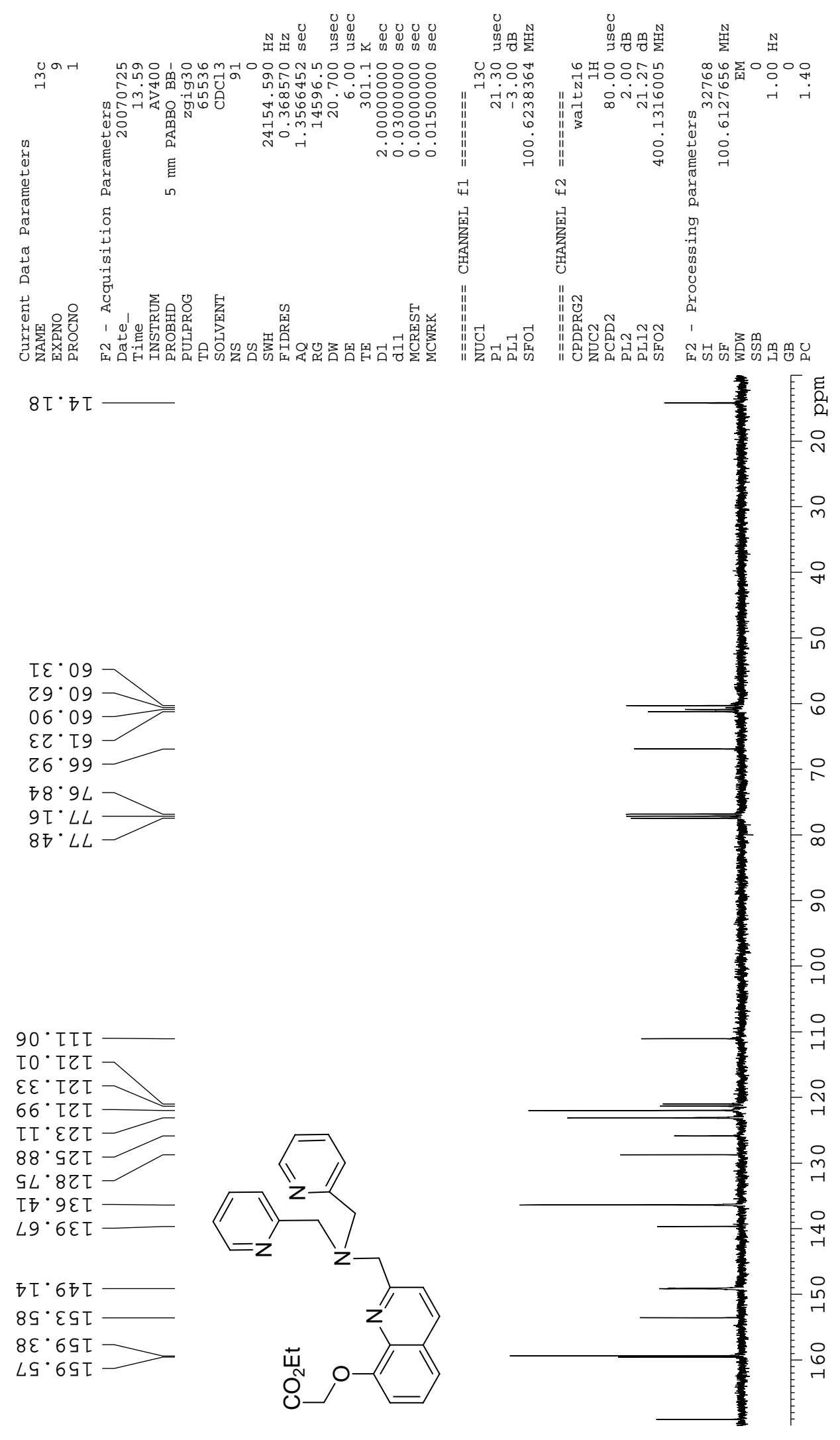




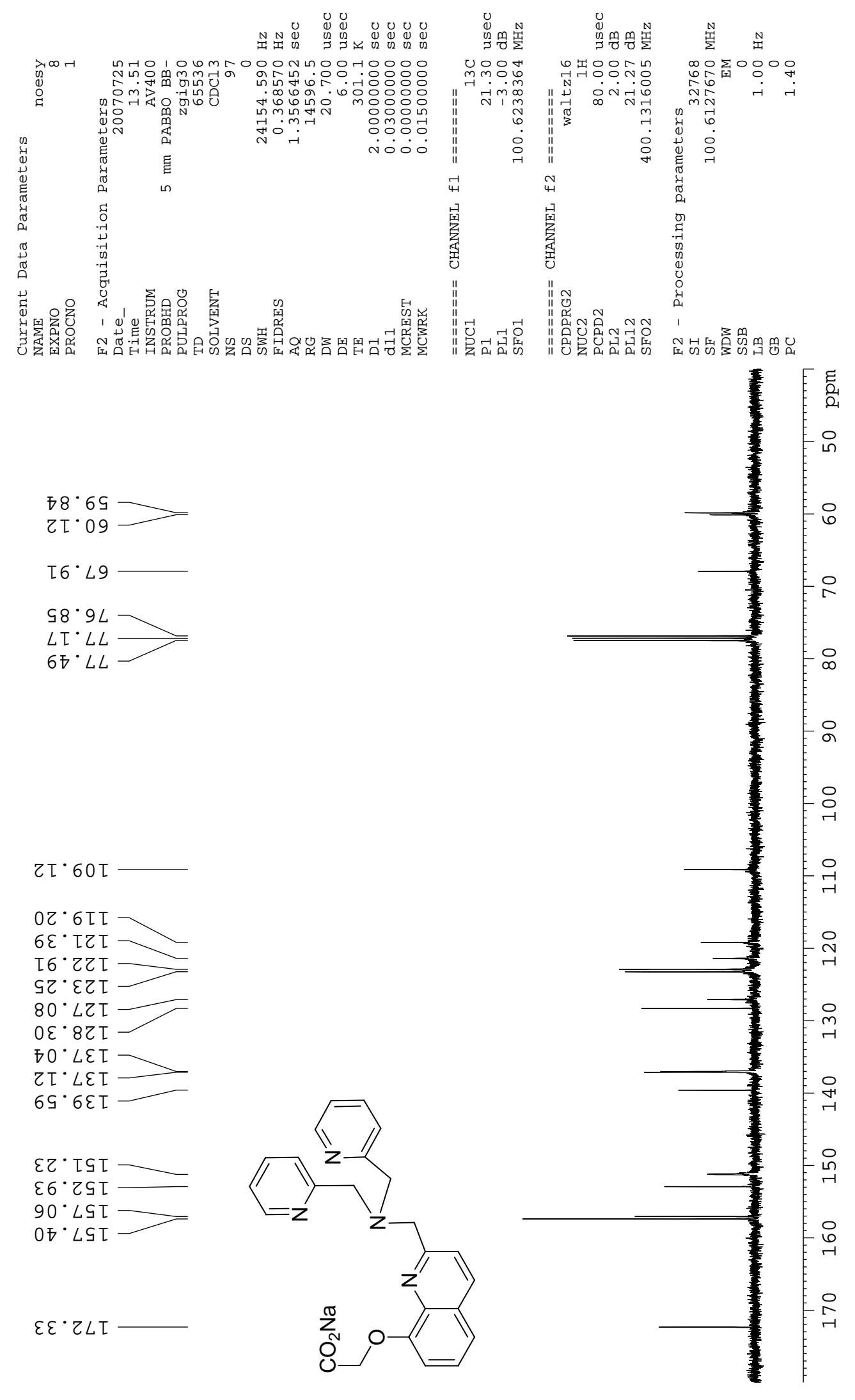

